\title{
The Initiatives to Strengthen Teachers' Online Learning Skills During the Covid-19 Pandemic
}

\author{
Tengku Muhammad Sahudra', Raja Novi Ariska ${ }^{2}$, Nursamsu3 \\ DOI: $10.35445 /$ alishlah.v13i3.883
}

\section{Article Info}

Keywords:

Upgrade;

Teacher Competence;

Online Learning

Kata kunci:

Peningkatan;

Kompetensi Guru;

Pembelajaran Online

\begin{abstract}
This study aimed to ascertain measures to enhance teachers' ability to teach online during the covid 19 pandemic. Action research is the research approach used in this type of research. The research was qualitative, describing the efforts to improve teachers' abilities to incorporate online learning into the teaching and learning process. This study was conducted at the MGMP for geography teachers at the senior high school and vocational high school level in Aceh Tamiang Regency. This study shows that teachers' competency in online learning is increasing, with the first cycle having a value of 0.45 per cent and the second cycle having a value of 0.80 per cent; hence, the two cycles predict growth in instructors using online learning in the future. Teachers can utilize a variety of technology-based online learning platforms, including Google Classroom, Edmodo, Quizizz, and Schoology.
\end{abstract}

\begin{abstract}
Abstrak
Tujuan dari penelitian ini adalah untuk mengetahui upaya dalam meningkatkan kemampuan guru selama pembelajaran daring pada masa pandemi covid 19. Metode penelitian yang dilaksanakan menggunakan jenis Penelitian ini adalah Penelitian Tindakan (action research). Penelitian yang dilakukan adalah penelitian kualitatif yaitu penelitian yang menjelaskan upaya-upaya yang dilakukan untuk meningkatkan kemampuan guru dalam melaksanakan pembelajaran daring pada proses belajar mengajar. Penelitian ini dilaksanakan di MGMP guru geografi tingkat SMA/SMK sederajat Kabupaten Aceh Tamiang sebanyak 20 orang guru. Hasil penelitian ini menunjukkan penerapan pembelajaran daring dengan mengukur peningkatan kompetensi guru yaitu siklus I bernilai $0,45 \%$ dinyatakan cukup sedangkan siklus II dengan nilai o,80\% dinyatakan mahir, maka dapat disimpulkan dari kedua siklus tersebut terjadi peningkatan guru dalam menerapkan pembelajaran daring pada masa pandemi covid-19. Guru mampu menggunakan berbagai macam pembelajaran daring berbasis teknologi seperti menggunakan layanan Google Classroom, Edmodo, Quizizz dan Schoology.
\end{abstract}

\footnotetext{
${ }^{1}$ Universitas Samudra, Aceh, Indonesia

Email: tengkusahudra@unsam.ac.id 2 Universitas Samudra, Aceh, Indonesia Email: rajanovia@unsam.ac.id 3. Universitas Samudra, Aceh, Indonesia Email: samsubio@unsam.ac.id
} 


\section{INTRODUCTION}

The development of the coronavirus pandemic, also known as COVID-19, has posed a number of issues for Indonesian educational institutions. Preparing for possible viral transmission, the government implemented policies ranging from social distance to physical separation to widespread societal restrictions to prevent the spread of the virus (PSBB). This condition necessitates people staying at home to study, work, and pray, among other things. Schools and other educational institutions were forced to abandon the face-to-face learning process as a result of this approach. Instead, the learning process is carried out online, and each student can complete it from the comfort of their own home. Following the Minister of Education and Culture's Circular Letter Number 4 of 2020, which concerns the implementation of education policies during the emergency period of the spread of the coronavirus disease (COVID-19), it is recommended that students complete their educational requirements from the comfort of their own homes through online learning.

Accessibility, connectivity, flexibility, and capacity is brought up in numerous forms of learning interactions when participating in online learning. Researchers Zhang and colleagues (2004) discovered that the internet and multimedia technologies could transform how knowledge is delivered and be used as an alternative to traditional classroom learning environments. Online learning is defined as learning that can bring students and lecturers together to carry out learning exchanges through the internet (Kuntarto, E.) (2017). According to Basori (2017: 42), online learning is defined as learning that takes place using electronic network equipment (LAN, WAN, or internet) to deliver interactive learning materials and advice. The support of mobile devices, such as smartphones or Android phones, laptops, PCs, tablets, and iPhones that can be used to access information at any time and from any location is required at the implementation level for online learning to be successful (Gikas \& Grant, 2013). Universities must strengthen online learning during the World Food Summit (WFH), according to the World Food Summit (Darmalaksana, 2020). Online learning has emerged as a popular option in higher education ( $\mathrm{He}, \mathrm{Xu}$, \& Kruck, 2014). Learning at home necessitates the use of online resources. It is essential for the fourth industrial revolution (sometimes known as the Fourth Industrial Revolution 4.0) (Pangondian et al., 2019).

The use of mobile technology in educational institutions, especially distance learning goals, has significantly contributed to the field (Korucu \& Alkan, 2011). There are several studies about using a variety of media that can be used to support the deployment of online learning. For example, virtual classrooms using Google Classroom, Edmodo, and Schoology services (Enriquez, 2014; Sicat, 2015; Iftakhar, 2016) and instant messaging programs such as WhatsApp are all examples of how technology may help (So, 2016). Even social media platforms such as Facebook and Instagram can be used to facilitate online learning (Kumar \& Nanda, 2018). When students use online learning, they are connected to learning resources (databases, experts/instructors, libraries, etc.) that are physically separated or far apart but can communicate, interact, or cooperate (both directly and indirectly/asynchronously). An example of online learning includes using telecommunications and information technology, such as the internet, CD-ROOM, and other similar tools to complete a course (Molinda, 2005).

Educators are professionals responsible for the planning and implementation of the learning process, the assessment of learning outcomes, the provision of guidance and training, the conduct of research, and the provision of community service, particularly for educators in higher education institutions. According to Article 39, paragraph 2 of Law Number 20 of 2003 governing the National Education System, the following assertion is made: (2003: 27). Professional teachers must be capable of putting learning programs into action. Programs into action One aspect that determines the achievement of learning and education goals in schools is the level of teacher competency. Pedagogic competence, personality competence, social competence, and professional 
competence are all defined in Article 10 paragraph 1 of Law No. 14 of 2005 concerning Teachers and Lecturers (2006:7). Teacher competence includes pedagogic competence, personality competence, social competence, and professional competence acquired through professional education. Of the four most important teacher competencies that teachers must possess is pedagogic competence. Pedagogic competence is the ability of teachers to manage the teaching and learning process, including the planning and implementation process, evaluation of teaching and learning outcomes and student development as individuals. Pedagogic competencies include: (1) Understanding students in-depth; (2) Designing learning, including understanding the educational foundation for the benefit of learning; (3) Implement learning; (4) Design and implement learning evaluations; (5) Developing students to actualize various potentials (Sadulloh, 2010).

The competence of teachers to prepare for learning activities includes the execution of learning media utilized by them in the learning activities. Furthermore, in today's digital age, teachers must be able to understand a wide range of technical media, which might impact their skills and competency as educators. Teachers who conduct learning activities are responsible for demonstrating mastery of their subject matter expertise. Pedagogic, personality, social, and professional abilities are all components of teacher competence that are interwoven into teachers' performance, as we all know (Agung, 2012). As a result, teachers must be adaptable, work hard, apply abilities/competencies, and build technology skills for education to contribute more to production and for students to achieve rapid competitiveness in mastering technology-based online learning, among other things. However, the reality is that many teachers are not taking advantage of technology-based learning opportunities. There are various fundamental reasons why teachers do not engage in learning in the period of the Fourth Industrial Revolution. According to the data collected, just 10 to 15 per cent of Indonesian teachers presently use technology in the classroom, out of 2.7 instructors in the country. The value represented by this figure is quite low, especially in light of the rapid advancement of technology. When it comes to improving the overall quality of learning, the usage of learning media in the classroom is highly recommended. Students can interact directly with learning materials tailored to their abilities and interests through learning media (Fadli, 2017).

According to the description above, mastering a technology-based learning medium becomes the most challenging obstacle for a teacher to face. According to Sanjaya (2006), learning media is a mode of communication used to deliver messages in learning. As recipients of messages, students grasp the content of messages in the form of learning materials (Hidayatullah, 2016). The goal of media is to improve performance and make it possible to carry out various operations more swiftly, precisely, and accurately (Hamzah, 2011). Additionally, the materials exhibited in the learning media can pique students' interest while also increasing their grasp of the materials displayed (Nuroifah, 2015). The explanation that has been presented serves as the foundation for our investigation into MGMP geography teachers at the SMA/SMK equivalent in Aceh Tamiang Regency by offering knowledge of various online learning programs. If they use online learning resources, teachers and students will find it easier to apply the learning method that the government has mandated during the COVID-19 epidemic.

\section{METHODS}

Action research was used as the method of choice for the study. Qualitative research is used in the study, which focuses on instructors' abilities to adopt online learning in their classrooms. This research was conducted at the Geography Teacher MGMP's comparable high school level, Aceh Tamiang Regency. All 20 Geography teachers at the SMA/SMK equivalent in Aceh Tamiang Regency were included in this study. Cycle I and Cycle II of this study were conducted (Arikunto, 2006:16). Students engaged in online learning activities during the first cycle, and the second cycle built on the gains made during the first. Cycle I's reflection served as a guide for cycle II's decisionmaking about remedial action. An online learning follow-up plan is based on this reflection. The 
first cycle was carried out in groups. The second cycle was carried out individually. The final data was collected through observation, documenting, and filling out the research instrument sheet through observation, documentation, and observation.

A comparative descriptive study of the data utilized by researchers, in this case, to compare how online learning is implemented. It is also compared with results after training to see how much progress has been made in presenting teachers' performance abilities in their classrooms through online learning.

\section{FINDINGS AND DISCUSSION}

The study team from the University of Samudra and the MGMP geography teacher from the SMA/SMK equivalent in Aceh Tamiang Regency worked together for two cycles to conduct the action research. Online learning is implemented in classrooms by teams of teachers that work together to increase each other's skills and knowledge. Twenty teachers of geography were surveyed as part of the study. Teachers' online learning competency is the primary emphasis for this action research. Teachers are assumed to have rules for taking actions for online learning activities in the classroom based on their geographic location if they can carry them out properly. Efforts were divided into two distinct phases. Figure 1 shows the outcomes of cycle 1 of research.

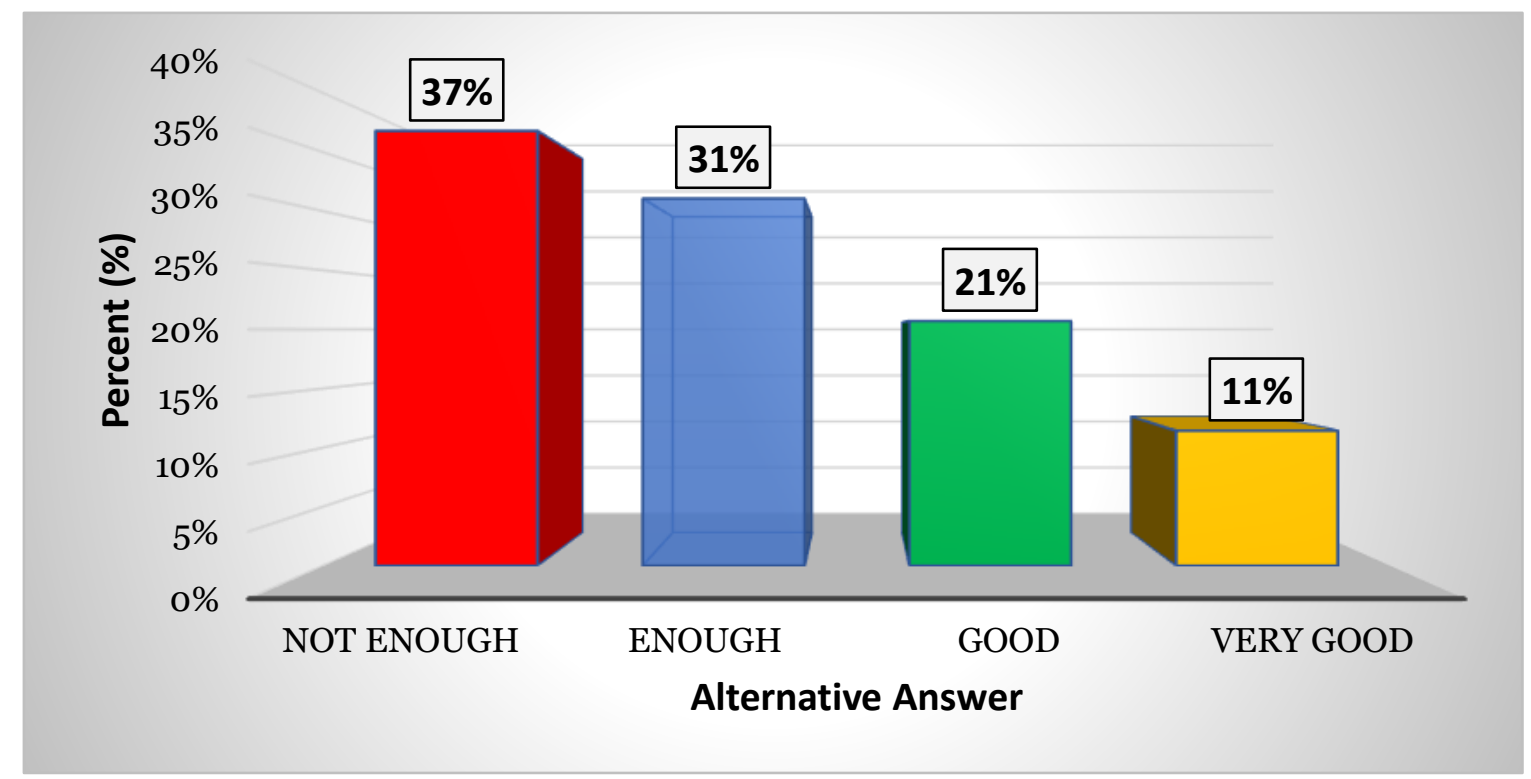

Figure 1. Teacher Understanding in Online Learning in Cycle I

Based on Figure 1, the teacher's understanding in online learning which consists of four answers explains that for a poor answer with a score of $37 \%$, a sufficient answer with a score of $31 \%$, while a good answer with a value of $21 \%$ and a very good answer with a value of $11 \%$. Furthermore, teacher understanding research in implementing online learning was carried out in cycle II, which can be seen in Figure 2 below. 


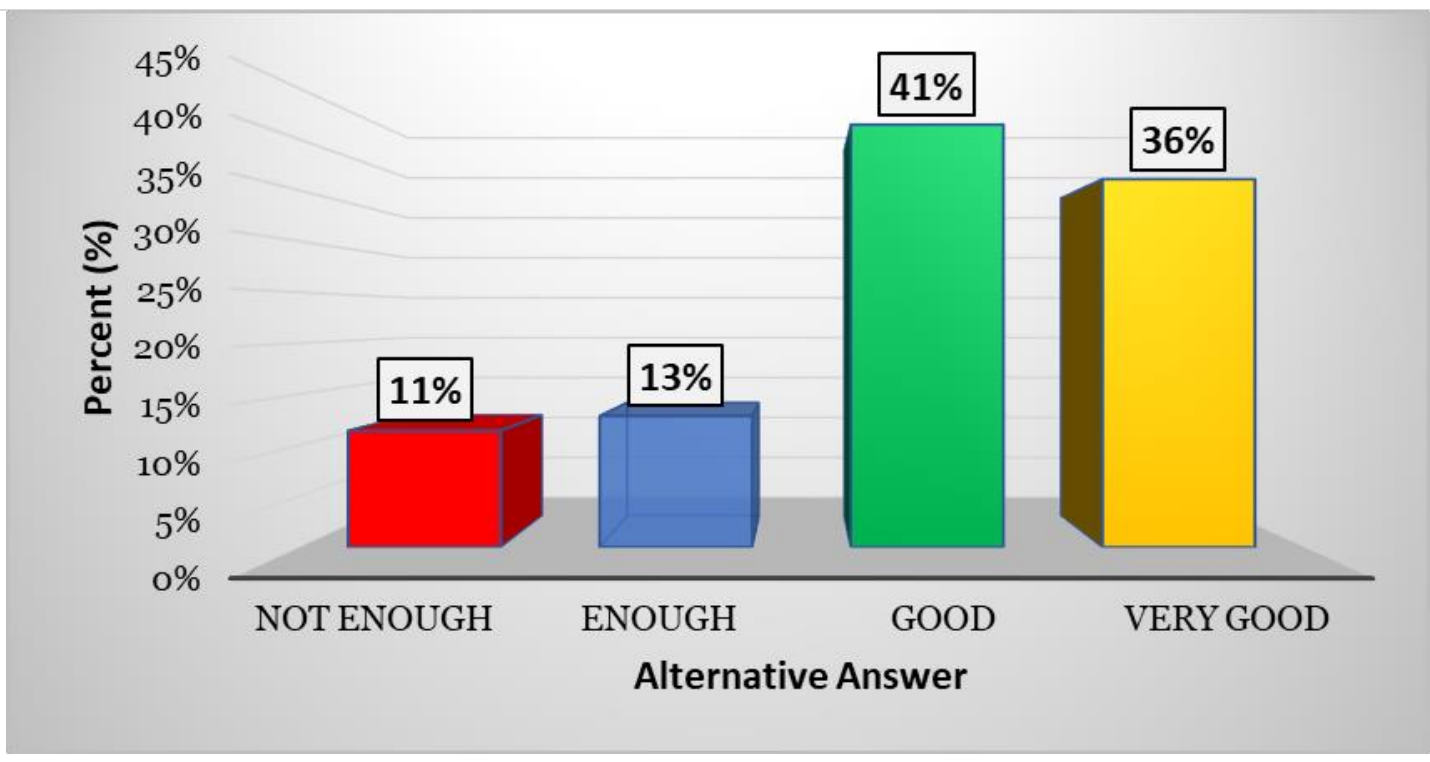

Figure 2. Teacher Understanding in Online Learning in Cycle II

The explanation of the results from Figure 2 regarding the teacher's understanding in online learning cycle II states that the alternative answer is less with a score of $11 \%$, the answer is sufficient with a value of $13 \%$, while the good answer is with a value of $41 \%$ and the alternative answer is very good with a value of $36 \%$. In the next stage, the calculation of the data on increasing the ability/competence of teachers from both cycles I and cycle II using the N-Gain formula can be seen in Figure 3 below.

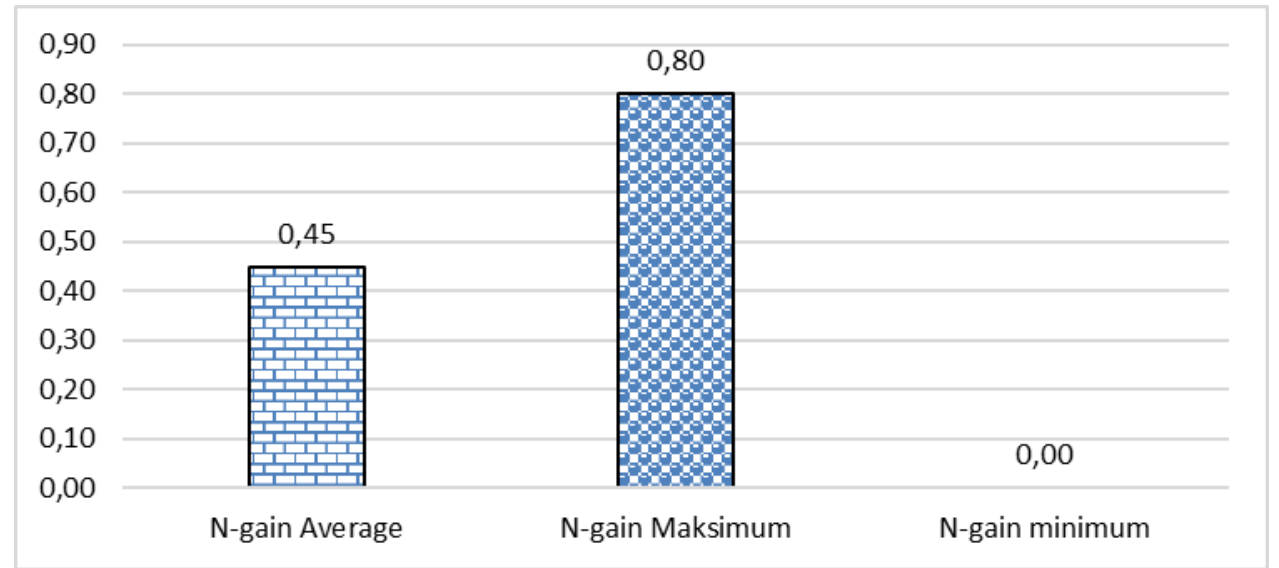

\section{Figure 3. Competency Improvement Cycle I and Cycle II in the Application of Online Learning}

Based on Figure 3 above explains the process of implementing online learning by measuring the increase in the ability/competence of teachers, namely the first cycle of $0.45 \%$ is declared sufficient. In comparison, the second cycle with a value of $0.80 \%$ is declared good, it can be concluded from the two cycles that there is an increase in teachers in implementing online learning during the covid-19 pandemic.

Study results show that geography teachers in Aceh Tamiang Regency better grasp the online learning performed during Covid-19 than before. Teachers aren't always at their best in the real world. From the findings of scientists' studies. Teachers must be given specialized training to keep up with the ever-changing world of online education. For example, according to the results of Naserly's research (2020), students and lecturers can engage directly via Zoom cloud meetings. However, this has the drawback of wasting power and being less productive if more than 20 students are in the classroom. According to Sun et al. (2008), research shows that students' 
happiness with online learning is influenced by the flexibility of time, learning techniques, and location. An additional benefit of online learning is that it encourages self-regulation. The use of online programs can help students learn independently (Oknisih and Suyoto, 2019). According to Sobron and Bayu (2019), online courses pique students' curiosity.

The skills possessed by teachers in utilizing ICT-based learning media are quite good. However, a lot of guidance is still needed in finding media and learning resources from the internet (Yusrizal et al., 2017). The teacher's skills in designing and producing media are included in the sufficient category while utilizing the media is good. Suggestions that can be given, teachers should further improve their competence in designing, producing and utilizing ICT-based learning media to support the learning process (Niarsa et al., 2013).

\section{CONCLUSION}

According to the study's findings, teachers' ability to apply online learning in cycles I and II has increased due to the availability of numerous technology-based online learning tools, such as Google Classroom, Edmodo, Quizizz, and Schoology. The focus of this study is focused on ways to improve teachers' online teaching abilities. Using this method, the evaluation data is derived from the student context. Data from studies are used to improve the quality of teaching. Educators at other educational institutions or schools can also benefit from this research on using online applications for teaching and learning. This indicates that research findings can impact educators' understanding of digital apps that can be employed for teaching and learning activities at school during the Covid-19 epidemic period. It's also worth noting that each region has a distinct history of delivering internet networks and the capacity of students to meet their online learning quotas.

\section{ACKNOWLEDGEMENT}

Thank you, the research team, to the University of Samudra's Institute for Research, Service and Quality Assurance, which has carried out excellent basic research activities from the 2021 budget DIPA funds.

\section{REFERENCES}

Agung, I. (2012). Menghasilkan Guru Kompeten dan Profesional. Jakarta : Bee Media Indonesia. Arikunto. 2006. Prosedur Penelitian Suatu Pendekatan Praktik. Edisi Revisi. Jakarta: Rineka Cipta

Basori, B. (2017). Efektifitas Komunikasi Pembelajaran Online Dengan Menggunakan Media ELearning Pada Perkuliahan Body Otomotif. Jurnal Ilmiah Pendidikan Teknik Dan Kejuruan, 7(2), 39-45.https://doi.org/10.20961/jiptek.v7i2.12722.

Darmalaksana, W. (2020). WhatsApp Kuliah Mobile . Fakultas Ushuluddin UIN Sunan Gunung Djati Bandung.

Enriquez, M. A. S. (2014). Students ' Perceptions on the Effectiveness of the Use ofEdmodo as a Supplementary Tool for Learning. DLSU Research Congress. https://doi.org/10.1017/CBO9781107415324.004

Fadli, A., Suharno, S., \& Musadad, A. A. (2017). Deskripsi Analisis Kebutuhan Media Pembelajaran Berbasis Role Play Game Education untuk Pembelajaran Matematika. In Prosiding Seminar NasionalTeknologi Pendidikan.

Gikas, J., \& Grant, M. M. (2013). Mobile computing devices in higher education: Student perspectives on learning with cellphones, smartphones \& social media. Internet and Higher Education. https://doi.org/10.1016/ijheduc.2013.06.002

Hamzah dan Nurdin (2011). Belajar dengan Pendekatan PAILKEM. Jakarta: Bumi Aksar

Hidayatullah, Muhammad Syarif. (2016). Pengembangan Media Pembelajaran Berba sis Flipbook Maker Pada Mata PelajaranElektronika Dasar di SMK Negeri 1 Sampang. Jurnal Pendidikan TeknikElektro, 5(1), 83-88. 
He, W., Xu, G., \& Kruck, S. (2014). Online IS education for the 21st Century . Journal of Information Systems Education.

Iftakhar, S. (2016). Google Classroom: What Works and How? Journal of Education and Social Sciences

Kuntarto, E. (2017). Keefektifan Model Pembelajaran Daring Dalam Perkuliahan Bahasa Indonesia Di Perguruan Tinggi. Indonesian Language Education and Literature, 03, 102.

Korucu, A. T., \& Alkan, A. (2011). Differences between m-learning (mobile learning) and elearning, basic terminology and usage of m-learning in education. Procedia - Social and Behavioral Sciences. https://doi.org/10.1016/j. sbspro.2011.04.029

Kumar, V., \& Nanda, P. (2018). Social Media in Higher Education. International Journal of Information and Communication Technology Education.

https://doi.org/10.4018/ijicte.2019010107

Kemdikbud RI. (2020). Pedoman Pembelajaran Jarak Jauh Masa Pandemi Covid-19

Molinda, M. (2005), Instructional Technology and Media for Learning New Jersey Colombus, Ohio

Nuroifah, N. (2015). Pengembangan MediaPembelajaran Berbasis Aplikasi Android Materi Sistem

Ekskresi Siswa Kelas XI SMAN1 Dawarblandong Mojokerto. Jurnal Mahasiswa Teknologi Pendidikan, 1(1).

Naserly, M. K. (2020). Implementasi Zoom, Google Classroom, Dan Whatsapp Group Dalam Mendukung Pembelajaran Daring(Online) Pada Mata Kuliah Bahasa Inggris Lanjut (Studi Kasus Pada 2 Kelas Semester 2, Jurusan Administrasi Bisnis, Fakultas Ekonomi dan Bisnis, Universitas Bina Sa. Aksara Public, 4(2), 155-165.

Niarsa dan Aditya. (2013). Studi kompetensi guru dalam memanfaatkan media pembelajaran berbasis teknologi informasi dan komonikasi (TIK) di SD NEGERI o1 Ledok Kecematan Sambong Kabupaten Blora. jurusan Kurikulum dan Teknologi Pendidikan, Fakultas Ilmu Pendidikan UNS Semarang.

Pangondian, R. A., Santosa, P. I., \& Nugroho, E. (2019). Faktor-Faktor Yang Mempengaruhi Kesuksesan Pembelajaran Daring Dalam Revolusi Industri 4.o. In Seminar Nasional Teknologi Komputer \& Sains (SAINTEKS) (Vol. 1, No. 1).

Oknisih, N., \& Suyoto, S. (2019). Penggunaan Aplen (Aplikasi Online) Sebagai Upaya Kemandirian Belajar Siswa. In SEMINAR NASIONAL PENDIDIKAN DASAR (Vol. 1, No. 01).

Sicat, A. S. (2015). Enhancing College Students' Proficiency in Business Writing Via Schoology. International Journal of Education and Research.

So, S. (2016). Mobile instant messaging support for teaching and learning in higher education. Internet and HigherEducation.https://doi.org/10.1016Zj.iheduc.2016.06.001

Sun, S. Y. H. (2014). Learner perspectives on fully online language learning. Distance Education. https://doi.org/10.1080/01587919.2014.891428

Sobron, A. N., \& Bayu, R. (2019). Persepsi Siswa Dalam Studi Pengaruh Daring Learning Terhadap Minat Belajar Ipa. SCAFFOLDING: Jurnal Pendidikan Islam dan Multikulturalisme, 1(2), 30-38.

Sanjaya, Wina. (2006). Strategi Pembelajaran Berorientasi Standar Proses Pendidikan. Bandung: Kencana.

Undang-Undang No. 14 Tahun 2005 tentang Guru dan Dosen

Usman Husaini. (2013). Manajemen Teori, Praktik, dan Riset Pendidikan. Bumi Aksara.

Yusrizal. (2017). Kompetensi Guru Dalam Memanfaatkan Media Pembelajaran Berbasis Teknologi Informasi Dan Komunikasi (Tik) Di Sd Negeri 16 Banda Aceh Jurnal Ilmiah Pendidikan Guru Sekolah Dasar FKIP Unsyiah Volume 2 Nomor 2, 126- 134.

Zhang, D., Zhao, J. L., Zhou, L., \& Nunamaker, J. F. (2004). Can e-learning replace classroom learning? Communications of the https://doi.org/10.1145/986213.986216 